\title{
Menstrual Taboos: Moving Beyond the Curse
}

\begin{abstract}
Alma Gottlieb
[Megyn Kelly] starts asking me all sorts of ridiculous questions . . you could see there was blood coming out of her eyes, blood coming out of her wherever.

-U.S. presidential candidate, Donald Trump, commenting on hard-hitting questioning by journalist Megyn Kelly. (Beckwith 2015)
\end{abstract}

The day after a challenging U.S. presidential debate, then-candidate Donald Trump complained about a female journalist's tough questions by appealing to biological reductionism. His seemingly ambiguous reference to 'her wherever' clearly intended to signify 'vagina'-thereby evoking menstrual blood, and its presumed adverse effects.

In appealing to menstrual blood as the go-to explanation for a female journalist's emphatic interviewing style, Trump revealed that he (like many others) views women as different from men in two crucial ways: ruled by their biology, and naturally meek. If women behave assertively-in ways widely admired for men but disparaged for women-their supposedly out-of-character behavior must be dictated by something beyond their control. That 'something' is often assumed to be hormones organized around the menstrual cycle, prompting menstruating women to express out-ofcontrol emotions, especially anger. In implicitly yet legibly evoking such longstanding gender stereotypes, Donald Trump signaled that menstrual taboos remain alive and well in the contemporary world.

In this chapter, I explore both historical and contemporary structures that undergird menstrual stereotypes and taboos. In the first section, I chart some religious foundations underlying widespread notions that menstruating

In memory of Franz Steiner-brilliant scholar of taboo who died before his time from the after-effects of stigma.

(C) The Author(s) 2020

C. Bobel et al. (eds.), The Palgrave Handbook of Critical Menstruation

Studies, https://doi.org/10.1007/978-981-15-0614-7_14 
women cause suffering both to themselves and others. I also explore some communities whose residents offer less negative interpretations. Here, I build on the work of Blood Magic: The Anthropology of Menstruation (Buckley and Gottlieb 1988b), a collection of feminist essays that helped inaugurate the modern anthropological study of menstruation practices and beliefs around the world. That collection introduced readers to a striking diversity of menstrual experiences, especially in the Global South. The essays argued that, despite shared biological roots, individuals and communities perceive and experience menstruation in enormously different ways, for reasons encompassing religious, political, demographic, and economic factors.

Today, lines between the Global South and the Global North are blurring. Examples of sometimes parallel, sometimes divergent menstrual experiences that appear below should remind readers that focusing on essentializing distinctions between 'us' and 'them' makes sense neither ethnographically nor ethically. In the second section, I explore briefly some important ways that diverse individuals and organizations are challenging classic stereotypes and taboos surrounding menstruation, forging an emerging global movement of menstrual activism (see Bozelko [Chapter 5]; Bobel and Fahs [Chapter 71]; Nyanzi [Chapter 42]; Weiss-Wolf [Chapter 41]; and Lewis [Chapter 58] in this volume). As with the meanings of taboos themselves, these acts of challenging taboos take various forms and involve diverse individuals across religion, ethnicity, class, caste, gender identity, and other factors.

\section{Understanding and Respecting Taboos}

In the United States, the catch-all term 'PMS'-short for 'premenstrual syndrome'-describes any otherwise-unexplained physical or emotional affliction that women of menstruating age experience before their menstrual period. (Though technically inaccurate, in many popular contexts, PMS is even evoked during and after menstrual periods.) In some accounts, a version of this condition reportedly affects up to $90 \%$ of all women (U.S. Department of Health and Human Services 2018). By definition, any 'syndrome' is something of a medical mystery (Mukherjee 2009). Anecdotally, patients report a set of co-occurring medical symptoms. However, science has not identified a shared cause. If and when such a cause is identified, the moniker 'syndrome' drops off, and a new name for an actual disease is assigned. With 'PMS,' more than 150 symptoms have found shelter under this very wide umbrella (Studd et al., n.d.; cf. Stolberg 2000). Since no scientific research has isolated a common etiology of these symptoms, the scientific justification for 'PMS' remains dubious (DeLuca 2015).

Even so, PMS has been creatively adapted into a popular neologism by being turned into a verb-as in, "she's PMS-ing." Despite the long list of symptoms, this neologism typically indexes just one symptom: the supposed tendency for a menstruating woman to lose control of her emotions in general, and to express annoyance, critique, or anger in particular (Gottlieb 
1988a). Both women and men who highlight this focus may evoke hormones to explain why they oppose women's holding top political positions, which they claim would imperil citizens, due to unpredictable decisions (for example, Bradner 2015). To minimize the supposed risks of undisciplined behavior, modern menstruating women remain subject to new versions of ancient taboos, whose exploration will be at the center of this chapter.

\section{Taboo}

For many modern readers, the word 'taboo' unconsciously evokes 'primitive' peoples from long ago or far away - people who unthinkingly obey(ed) arbitrary rules that restrict their lives and thoughts. Yet, images of menstruation as symbolically polluting retain strong staying power in a world ostensibly ruled by science (cf. Coronil 1997; Goffman 1963; Little 2012; Miner 1956; Moeran 2014). Even highly educated women perpetuate menstrual taboos in intimate and public ways alike. Robust research across several decades on the many euphemisms women use for their periods signals how sociologically taboo it remains for women in many settings to discuss this basic biological function (for example, Cauterucci 2016; Chrisler 2011; Ernster 1975; Thornton 2013). No matter their metaphoric content, these euphemisms share one goal: to avoid clear biological descriptors such as 'menstruation,' 'menstrual period,' or 'period' (Kissling 1996; Newton 2016; for examples beyond English, see Escaja 2018; Ren, Simon, and Wu 2018).

Words tell a story. So do efforts to avoid words. The discursive act of substituting euphemisms for certain words brings us straight to the territory of taboo. Words to be avoided carry what the philosopher John Austin (1962) dubbed an "anti-illocutionary force"-the opposite of the illocutionary force conveyed by words that are spoken (rather than avoided). Words silenced by euphemisms put us square in the realm of the "magical power of words," as anthropologist S. J. Tambiah termed it (1968). Uttering phrases normally avoided violates the taboo-incurring emotional, sociological, spiritual, and/or political risks (cf. Allan and Burridge 2006; Pedraza 2018).

Why do words describing a biological process experienced by half our species have this symbolic power? I suggest that, in many parts of the world, the effort to circumvent speaking about menstruation in simple, neutral, or scientific terms and to rely, instead, on euphemisms that often involve shame and/or censure has deep roots in patriarchal ideology inherent in the Jewish and Christian traditions (and later adopted in Islam) (cf. Buckley and Gottlieb 1988a, 32). Of the many English-language euphemisms documented by scholars, one phrase recurs: "the curse." In a study conducted in Oregon, 50\% of English-speaking women (aged 18-80) referred to menstrual periods as "the curse" (Lee 1994). 


\section{Menstruation as Curse}

Why a curse? At one level, one might cite certain biological facts that could produce this dramatically negative view. Menstrual blood differs in many ways from venous blood. It cannot clot (Yang et al. 2012). It flows only from a single place in the body. It stops flowing of its own accord and should not be staunched; an obstructed flow (or amenorrhea) generally signals a problem such as polyps, fibroids, an eating disorder, a birth defect, or a genetic disorder (Pinkerton 2017). Although it may cause suffering, it rarely causes unstoppable hemorrhaging, hence it is rarely lethal. Menstrual blood is typically associated with only one gender-although, as discussed below, not universally. Perhaps a combination of these characteristics has endowed menstrual blood with mystical properties; hence, menstrual blood might readily become subject to taboos-mystically based rules that govern who may (and may not) touch, see, or speak about it (Steiner 1956).

However, none of these characteristics should inevitably produce a notion of a spiritual curse causing women's menstrual suffering. Rather, in Western/ ized nations, the widespread concept of menstruation-as-curse likely derives from one specific religious tradition: the Jewish and Christian traditions' sacred text, the Bible. In the Hebrew Bible (a.k.a. the Pentateuch or Old Testament in Christianity), the first book, Genesis, explains that the mythical first woman, Eve, disobeyed her god by eating a forbidden apple. While Genesis names the pain of childbirth, not menstruation, as the curse for Eve's transgression, the Bible's third book, Leviticus, mentions the pain of menstruation and lists required and forbidden activities for menstruating women. Perhaps building on early Mesopotamian ideas about purity (Morrow 2017), generations of Bible readers - both Jewish and, later, Christian-have associated the two stories, such that menstruation is widely considered, and named, a curse like childbirth. As O'Grady has written $(2003,5)$ :

many biblical commentators throughout history have viewed the Levitical menstrual prohibitions as divine punishment for the sinful nature of woman, which, through the actions of Eve, effected the fall of humankind. Menstruation becomes the divine "curse" of women.

As early as the sixth century, Pope Gregory made this association, and across the ensuing 15 centuries, the popular interpretation has had authoritative theological foundations (Wood 1981, 713-14). One scholar argued that Hebrew Biblebased menstrual taboos account for the continuing exclusion of women from high office in many Jewish and Christian congregations, organizations, and communities (Phipps 1980; see also Cohen [Chapter 11] in this volume). As the third Abrahamic religion, Islam's sacred book, the Qu'ran, retained a version of these views, with menstruation deemed a "painful condition." In most modern Muslim communities, fasting during Ramadan, entering a mosque, praying, having sex, and making the full pilgrimage to Mecca are all forbidden 
for menstruating women (Ahmed 2015; Haleem 2011), although the textual basis of these injunctions is sometimes debated (Lizzio 2013; cf. Mazuz 2012; see also Maharaj and Winkler [Chapter 15] in this volume).

In short, the menstrual lessons of Genesis and Leviticus have cast a wide shadow across both time and space. Although Jews have always constituted a tiny proportion of humans (in 2015, a mere $0.2 \%$ - see Hackett and McClendon 2017), their religious heirs-first Christians, then Muslims-have expanded to constitute, collectively, some $54 \%$ of the world's contemporary population (Pew Research Center 2015). From many centuries of missionary and military activity, the impact of these two proselytizing religions has meant that virtually no community anywhere remains untouched by one or another of their teachings (for example, Comaroff and Comaroff [1991] 1997; Pawliková-Vilhanová 2007), and menstrual lessons stemming from the three religions are widely known and accepted (although Hinduism and other religions may have their own origins for menstrual taboos). My discussion of the Jewish-Christian-Muslim tradition of 'the curse' is intentionally broad here, precisely because it is a dominant (though not hegemonic) perspective across much of the world, despite local variations, interpretations, and contestations.

If the dominant legacy of the Jewish-Christian-Muslim heritage propagates an image of menstruation-as-curse, what, exactly, is meant by the term? The Oxford English Dictionary (OED) defines a curse as: "la. An utterance consigning, or supposed or intended to consign, (a person or thing) to spiritual and temporal evil, the vengeance of the deity, the blasting of malignant fate, etc. It may be uttered by the deity, or by persons supposed to speak in his $[s i c]$ name, or to be listened to by him [sic]." This definition signals that certain unfortunate events presumably emanate from spiritual entities. A later definition further highlights the notion of divine punishment: " $4 \mathrm{a}$. The evil inflicted by divine (or supernatural) power in response to an imprecation, or in the way of retributive punishment." Implied in both definitions is an assumption of inevitability. The very notion of a god relies on the assertion of a power greater than that of humans. If a god curses a human, the suffering is, by definition, inexorable. A further OED definition specifically links women's menstrual experience with such inevitable suffering-“ $4 \mathrm{~d}$. the curse: menstruation. colloquial."

With the notion of a curse come specific behaviors and practices that, typically, communities require and women internalize. In communities influenced by the three Abrahamic religions and not (yet) experiencing challenges to their orthodoxies, notions of symbolic 'pollution' and 'stigma' typically join that of 'the curse' to ostracize menstruating girls and women on discursive, conceptual, and physical registers. 'Pollution' normatively becomes the community idiom through which 'stigma' assigns menstruators blame for the symbolic danger they represent. Even when religious discourses are absent, a powerful 'yuck factor' frequently teaches menstruators to maintain their 
distance from non-menstruators (and vice versa), both verbally and spatially. In these ways, conventional expectations concerning taboo behavior spread well beyond communities oriented around the Bible or the Qur'an. But are all taboos created equal?

\section{Taboo as Morally Neutral}

In its original context, the Polynesian word, tap $u$-from which we derive the English 'taboo'-refers to a state of being too powerful to discuss or act on (Steiner 1956). In Polynesian societies, neither positive nor negative associations inevitably apply; the word simply evokes the notion of morally neutral power. When applied to earlier menstrual practices in Polynesian societies, tapu often lacked negative associations of stigma.

For example, in some Austronesian language-speaking societies in Polynesia, such as the Micronesian atoll of Ulithi, menstruators were traditionally categorized as tapu and, as such, were required to distance themselves from the community, in offsite buildings (Lessa 1966). But such 'menstrual huts' normally drew several menstruating women at once. Taking advantage of what the philosopher Alfred Schutz (1967) might have classified as "consociality," co-menstruating women in the same structure often pursued crafts and other relaxing activities together. In this way, what an outsider might have perceived as a stigmatizing exile could feel like a welcome space of female sociability and rest. On the nearby island of Yap, women maintained a similar tradition. In the 1990 s, they renamed the building for menstruating women the Faliyon Women Association's Cultural Center (Beardsley 1999). Among the Kwaio, yet another Austronesian-speaking community on the Solomon Islands, stringent menstrual taboos used to work to women's advantage by giving them access to spiritual power of ancestors (Keesing 1982); however, more recently these taboos have worked against women, for complicated reasons relating to anti-colonial protests and other components of modernity (Akin 2003). Their situation demonstrates the dynamic nature of taboos, which may change meanings across eras.

The notion of power as morally neutral, including as it relates to menstruation, exists far beyond Polynesia. In West Africa, the Beng people of Côte d'Ivoire traditionally partake of this view, using power in both supportive and destructive ways (Gottlieb 1989, 1992). This nuanced orientation contrasts markedly with a dominant Western ethos, which, rooted in the binary thinking of Plato and other ancient scholars, typically insists on moral decisiveness and excludes moral ambiguity: Things are either good or badnot both or neither. By contrast, with a conceptual orientation rooted in non-binary thought, the Beng view taboos as morally neutral.

Menstruating Beng women are subject to several taboos, including prohibitions on entering the forest, where their fields are located (otherwise they may experience difficulty in their next childbirth), and on touching a corpse (otherwise they may suffer a state of perpetual menstruation). 
However, these two prohibitions do not derive from a view of menstrual blood as inherently evil or polluting. Rather, menstrual blood is considered a symbol of human fertility, hence it should be separated from both vegetal fertility (agricultural fields) and death (corpses) (Gottlieb 1992). An indigenous male priest (or "Master of the Earth") of the Beng religion, Kouassi Kokla, explained:

Menstrual blood is special because it carries in it a living being. It works like a tree. Before bearing fruit, a tree must first bear flowers. Menstrual blood is like the flower: it must emerge before the fruit-the baby-is born. Childbirth is like a tree finally bearing fruit, which the woman then gathers. (personal communication with author)

In evoking this metaphor, Kokla implied that menstrual taboos do not derive from pollution ideologies. Rather, they separate two kinds of fertility (human vs. vegetable), and they separate life (human fertility symbolized by menstrual blood) from death (corpses). This view of menstrual taboos speaks to broader ontological axioms, rather than patriarchal notions of female pollution. The fact that red palm nut sauce cooked for many hours by a menstruating woman is considered by most Beng people to be the most delicious of the many sauces locally available further signals a positive view of menstruation held by men and women alike (Gottlieb 1988b).

\section{Taboo as Morally Ambivalent}

Taboos may link to visions that are fully positive, fully negative, or neutral. They may also, in some communities, signal ambiguity, even ambivalence. As documented by a British colonial officer's report, in the early twentieth century the Asante people of Ghana held a morally ambivalent valuation of menstruation. According to Rattray's 1927 study, menstruating Asante girls and women traditionally maintained numerous taboos, including avoiding cooking for any adult men (including a husband), swearing an oath, crossing certain rivers deemed sacred, and touching certain drums and amulets. In earlier days, if a menstruating woman entered the shrine where ancestral stools were kept, she would have been immediately killed (74-75). These practices imply a view of menstrual blood and menstruating women as polluting and evil in the extreme.

However, these taboos, along with the draconian punishment for their violators, only told part of the story. Traditional Asante priests incorporated menstrual blood into mystically powerful brooms (kunkuma) that purportedly protected them from mystical harm (Rattray 1927, 14). This practice suggests a view of menstrual blood as both powerful and able to be harnessed for good. Indeed, the above-mentioned taboos were kept from fear that a menstruating woman's spiritual powers were so strong that they could annul men's powers (Rattray 1927, 75). More recently, an indigenous scholar reported 
that Asante women may still use menstrual blood to make "love charms and potions" (Agyekum 2002, 377).

Adding further complexity to menstruation's moral biography, Asante communities traditionally celebrated menarche with an empowering ritual. Publicly seated beneath an enormous, beautiful, hand-made umbrella of the sort normally reserved for kings, queen mothers, and chiefs, girls menstruating for the first time traditionally received gifts and congratulations, while community members sang and danced in their honor (Rattray 1927, 69-74). Some reports suggest that the ritual, called bragors, remains vibrant today (Agyekum 2002, 380; Akwasi 2018). In the 1990s, this ritual proved important enough for some migrating families to bring to New York (Daniels 1991).

The ambivalence outlined above finds expression in language. Euphemisms for menstruation in the Akan languages spoken by the Asante and other linguistically related groups include phrases that emphasize "indisposition" and "seclusion" (Agyekum 2002, 372) and view menstruation as "toxic," "polluting," "revolting," and "dreadful" (ibid., 374). However, these negative terms are counterbalanced by phrases that emphasize "transition" (ibid., 379-81), "menstruation as a protective visitor" (ibid., 382), and "the importance (power, purification, and fertility) of menstruation" (ibid., 374; original emphasis), and that suggest pride in "the fertility and societal recognition of the female" (ibid., 367). The official euphemism to tell an Asante queen mother that an Asante girl under her jurisdiction has her first period is the phrase, $っ-a-y \varepsilon b r a$-literally, "she has been made perfect" (ibid., 380). In short, the complex set of Asante practices surrounding menstrual blood includes both extremely negative and extremely positive associations. A multilayered view of menstrual symbolism among the Asante leads us far beyond a simple model of menstruation-as-pollution.

Such multilayered perspectives on menstruation exist in many other communities. For example, among the native Yurok of northern California, aristocratic women celebrated their periods with ten days of rituals that accrued prestige to them by heightening spiritual powers, while commoners lacked this privilege (Buckley 1988). In southern India, social class (inflected by the traditional Hindu caste system) shapes menstrual experiences differently. There, menarche rituals still practiced today teach young women ambiguous lessons about their sexuality and social position: Girls learn that their periods are sources of power that may either enhance or disrupt their families' sense of honor and caste standing and, for that reason, they must be monitored carefully (Cardiff 2016; see also Sukumar [Chapter 13] in this volume). On the Balinese island of Indonesia (historically influenced strongly by India), menstruating women refrain from entering a Hindu temple, cooking, having sex, and touching certain objects of men. In some circumstances, they must even sit atop a trash heap. At the same time, all menstruating women enjoy the symbolic status of a raja, or prince (Pedersen 2002). Even so, class further distinguishes menstruating women's experiences. High-caste Balinese women may enjoy prestige from their periods, yet they must also adhere 
to additional menstrual (and other) restrictions that significantly limit their autonomy. Low-caste women may not receive prestige from their periods nor face extensive menstrual restrictions, but their overall lower status may leave them feeling oppressed for different reasons (Pedersen 2002, 309-11). The complicated Yurok and Balinese cases argue for a nuanced approach that prioritizes local experiences and acknowledges multilayered value systems. Rather than starting from an assumption of menstrual experience as a biological given that identically shapes all menstruators in a community, the diverse anthropological record urges us to start inductively. How do individual menstruators experience their periods? How do others perceive them? And how do local value systems, power structures, and menstrual technologies shape these perceptions? These questions provide the most productive starting points for any menstrual inquiry.

\section{Taboo and Shame}

In contrast to the cases just discussed, Western interpretations of tapu have emphasized an exclusively negative moral valuation of taboo, for reasons, as noted earlier, related to the dominant philosophical orientation of dualism (Buckley and Gottlieb 1988a). With this emphasis on menstruation as taboo, a girl or woman in such communities who speaks openly of her period, especially if boys or men are present, is considered scandalous (Brumberg 1993; Houppert 1999).

In communities pervaded by such expectations, speaking of menstrual experiences even with medical staff may produce shame. In one study in Sweden, only 38\% of women who suffered from excessive menstrual bleeding reported their condition to their doctors (Kadir, Edlund, and von Mackensen 2010). One medical researcher suggested, "Social taboos related to menstruation . . may explain why women have a reluctance to discuss issues relating to menstruation with clinicians, especially male clinicians" (McLintock 2018, 24). Researchers point out that when the taboo on discussing menstruation applies to medical staff, health risks may result. Moreover, reluctance to seek help and information can lead to misunderstanding that can incline some women to seek unnecessary hysterectomies (O'Flynn 2006) or neglect detection of endometriosis (Seear 2009). A recent editorial in The Lancet (2018), notes: "In the UK, nearly 80\% of adolescent girls have experienced concerning menstrual symptoms (such as unusually heavy or irregular bleeding) but hadn't consulted a health professional; $27 \%$ of those said they were too embarrassed to discuss the topic. The rooted silence surrounding periods is putting lives at risk."

It is not just words that are problematic. Equally powerful social expectations restrain behavior surrounding menstruating and menstruators. As I have suggested, the biblical story of menstruation-as-curse is widespread, especially in Western(ized) nations-but not universal. I have mentioned several communities in Africa and Asia in which the biblical/qur'anic interpretation of 
menstruation as a curse has no hold; many other such communities exist elsewhere (for example Baldy 2018; Hoskins 2002a; Maggi 2002). Even so, not all women accept dominant norms, even when influenced by the Bible or the Qur'an. These norms may appear universal because of their broad discursive power, but they are not hegemonic. Moreover, the ways that menstruators challenge taboos vary from community to community and from person to person. In the next section, I survey some contemporary challenges to normative, taboo-based menstrual regimes; many of these find fuller discussion in other chapters in this collection.

\section{Menstrual Politics: Defying Taboos}

Increasingly, women around the globe confront and contest inequalities that some menstrual taboos create. In this section, I briefly survey some of these social protests. The heterogeneity of this menstrual activism echoes the diversity of the taboos' meanings and social contexts. As with the act of following taboos, decisions to contest them originate in diverse motivations and have diverse repercussions.

\section{An Emerging Menstrual Movement}

Culturally rooted taboos have proven difficult to contest. However, once challenged systematically, taboos may erode surprisingly quickly. The groundswell of political action now protesting menstrual product taxes, sick leave inequity, unaffordability and environmental unsustainability of menstrual supplies, and toxicity in menstrual products becomes an instantly effective rejection of taboo-merely by publicly acknowledging menstruation in the first place. Put differently, challenging menstrual taboos revalues the experience of menstruation by normalizing it; menstrual blood becomes another ordinary bodily substance. Popular new texts challenge menstrual taboos (Stein and Kim 2009; Weiss-Wolf 2017), whether through memoirs (Farrell 2018), manifestos (Okamoto 2018), educational comic books (Gupta et al., n.d.), fiction (Walter 2016), or coloring books (Clemmer 2016). Menstruation-themed websites, podcasts, and blogs abound (for example, Bell 2014; Clancy, n.d.; Nilson, n.d.; Williams, n.d.). Smartphone apps help women track their cycles (Wortham 2014). "Menstrual Hygiene Day" promotes global conversations (About Menstrual Hygiene [MH] Day, n.d.). Menstruating athletes run marathons while 'free bleeding'-trailing 26 miles of blood to protest menstrual stigma (Gandhi 2015). Politicians position themselves publicly as 'period rights activists' (TedMed, n.d.). These diverse projects announce new approaches that, however distinct their specific origins and goals, together challenge longstanding menstrual taboos. 


\section{Challenging Menstrual Taboos}

What happens when activists weaponize menstrual blood itself? In contesting inequalities, some activists use blood as a symbolic signifier, rendering public what normally remains private. Women of Northern Ireland harnessed this potent symbolism in a jailhouse protest. When 30 women who had been imprisoned for their fight for independence from Great Britain suffered egregious treatment in jail, they organized in 1980 to smear their menstrual blood on the prison walls (O'Keefe 2006). This protest took its force simply by violating standard menstrual taboos. The dramatic demonstration not only caught the attention of prison guards; one scholar argues that the 'Dirty Protest,' as it came to be called, later empowered a full-blown 'republican feminism' advocating a wide variety of women's rights beyond full independence from the UK. For example, it resulted in a landmark policy document approved by Sinn Féin (Northern Ireland's main nationalist party) arguing for "increased access to divorce, public childcare, childcare to be shared by both parents, free and accessible contraception [...], [and] non-directive pregnancy counseling and sex education" (ibid., 550-51). This case suggests that menstrual politics offer powerful options for women simultaneously exploiting and exploding menstrual taboos in support of broad social justice movements.

With the menstrual movement gaining force, some scholars warn of Eurocentric bias inadvertently introduced by efforts that ignore local menstrual culture and import culturally specific ideas about hygiene (Baldy 2016; Bobel 2019; Khoja-Moolji and Ohito 2018; Lahiri-Dutt 2014). As the menstrual movement spreads, such warnings will no doubt gain force. For example, not all menstruators endeavor to catch their flow of blood. Perhaps the most well-documented community of 'free bleeders' is that of the Rungus people of Borneo, whose longhouses elevated on stilts feature a space accommodating free-flowing menstrual blood:

During the time of heaviest flow a woman chooses less strenuous tasks which can be performed while sitting on the longhouse verandah. She sits with her skirt discreetly pulled up and her legs covered with a cloth ... If she gets up to move about she simply flushes the floor of [widely spaced] bamboo slats with water from a bamboo tube which is kept handy to clean up after all messes, including puddling babies [who urinate freely], and [other] spills. (Appell 1988, 110)

This publicly visible practice contributes to men and boys accepting menstruation as a normal and natural occurrence in women's lives (ibid.).

Such a space for free bleeding requires another luxury - the time to sit and bleed, without having to do strenuous work. Elsewhere, such moments characterize 'menstrual huts' as spaces for contemplation, relaxation, or spiritual renewal (Baldy 2018; Buckley 1988). However, some of these structures notoriously carry dangers because of their location. In some communities in the Far-Western region of Nepal, these include exposure to extreme 
weather, wildlife, and sexual assault (for example, Kadariya and Aro 2015; see also Rothchild and Piya [Chapter 66] in this volume). Although Nepal has criminalized these huts, and some Nepalese activists seek to abolish the institution-sometimes after observing menstrual-hut-based tragedy (White, Sharma, and Das 2013) — some communities continue to use them (Alayyan and Agence France-Presse 2017; Thorpe 2016). The Nepalese case reminds us to listen to the multiplicity of voices and perspectives seeking effective ways to address the strictures, and dangers, of some menstrual taboos.

Israel presents another scenario. There, some Ethiopian Jewish immigrants have brought their tradition of menstrual shelters to their new countryadapting immigration center caravans and, later, building small structures in their own back yards. For these women, retaining a modern version of menstrual structures becomes a means of asserting ethnic identity in a new land, and a counter-protest against a frequently unwelcoming environment (Cicurel and Sharaby 2007). In that sense, these women evoke the logic of Muslim feminists in Egypt, Iran, and elsewhere who have insisted on 're-veiling' as a political statement of independence, after colonial European powers compelled them to abandon their veils (Scott 2007). These and other cases attest to how defying taboos can take many forms-from opposing traditional menstrual practices to reclaiming them.

\section{Getting Creative with Activism}

It is now over 40 years since Gloria Steinem (1978) published her pathbreaking, counterfactual, feminist fantasy, "If Men Could Menstruate." Hundreds of thousands of women have likely read that essay; many of those readers are now raising their own daughters and granddaughters. These grand/mothers have rethought their menstrual experiences and are socializing girls to speak openly of all things period-related. Some host parties to celebrate first periods (for example, Bobel 2010), sometimes borrowing from empowering menarche rituals of communities they have read about, such as those of the Asante. These grand/mothers may simply aim to break the taboo against discussing menstruation. Others aim to implant in their girls a positive view of menstrual blood, even evoking women's sacred powers of fertility, perhaps taking inspiration from new menstrual rituals (Amberston 1994). Still others ally themselves loosely with a 'neo-pagan' identity, reimagining their relationship to the Christian icon Mary Magdalene, sometimes even leaving menstrual offerings while on pilgrimages in France and Spain (Fedele 2014). Elsewhere, artists produce paintings, mixed-media, video, and performance art pieces depicting menstrual experiences, sometimes using menstrual blood as their medium (Fahs 2016; Kutis 2019; Manica and Rios 2017). This new creative energy further signals the multiple connotations of menstrual blood among both menstruators and non-menstruators.

This variety of approaches also encompasses gender identity. Long ago, anthropologist Ian Hogbin ([1970] 1996) documented an "island of 
menstruating men" in New Guinea, where Wogeo men engaged in monthly "sub-incision" rituals. Cutting their penis, Wogeo men produced blood to purify themselves of what Wogeo religion claimed is pollution caused by the act of heterosexual sex. In this ritual, Wogeo men imitated the menstrual cycle of women - which, the Wogeo said, accomplished naturally the same aim of purifying women's bodies from the pollution of sex.

Although their motivations and strategies differ, some young menstrual activists beyond New Guinea likewise claim that women do not hold a monopoly on menstruation (nor do all women menstruate regularly). In a conference panel addressing transgender identities in menstrual experiences, Clemmer (2017) urged the audience: "Why have a 'feminine hygiene' aisle? . . . Don't assume women $=$ menstruators (and vice versa). . . . We need to give up [using] 'feminine products' and other outdated phrases. . . . We need to avoid the conversation being just about ciswomen!" In the same panel, another activist commented, "There are some companies that specifically make products for trans[-gendered] people. That's great, but NO companies should include gendered language that erases trans/non-binary identities. . . . ALL products should be genderinclusive, including of trans people" (Pierce 2017).

With such comments, activist youth challenge the classic binary opposition distinguishing male from female. Echoing work on the cultural construction of gender by the farsighted Margaret Mead (1935, 1949), these menstrual activists are reimagining the menstrual experience from the ground up-and insisting (as anthropologists are wont to do) on its plural nature. The impressive variety of forms that individuals, communities, and organizations are taking to challenge debilitating menstrual taboos further supports the key point noted thirty years ago by anthropologists (Buckley and Gottlieb 1988b): menstrual blood, as with other bodily fluids and processes, holds different meanings for different individuals and across diverse communities. It follows that challenging, defying, and reimagining these meanings also takes a variety of forms.

\section{Concluding Thoughts}

In 2009, Nigerian writer Chimamanda Ngozi Adichie powerfully reminded a "TED Talk" audience of "the danger of a single story." As edited collections of anthropological work have demonstrated (Buckley and Gottlieb 1988a; Hoskins 2002b), research in communities around the world documents the striking variety of individuals' experiences of menstruation. Along with the variety of communities' normative attitudes and claims regarding menstrual blood, the global portrait of menstruation supports Adichie's general point.

It is true that biblical and, later, qur'anic views of menstrual blood as dirty, pain-inducing, and/or polluting - and of menstruating women as cursed-have traveled globally. However, as this chapter suggests, members of some indigenous communities continue to hold more positive, nuanced, 
or complicated views of menstruation. Moreover, in recent years, the quasihegemonic, Jewish and Christian view of menstrual blood as caused by a deity's curse-therefore polluting and stigmatizing - increasingly encounters resistance in the Western world. Furthermore, with ever-expanding global communications, both in person and online, the lines dividing experiences in the Global South and the Global North are blurring. One product of this impactful border-crossing is that negative attitudes regarding menstruation, along with hygienic and social practices, are beginning to change-in some places, both rapidly and for the better.

\section{REFERENCES}

About Menstrual Hygiene (MH) Day. n.d. http://menstrualhygieneday.org/about/ about-mhday/.

Adichie, Chimamanda Ngozi. 2009. "The Danger of a Single Story." TED Global Talk. Filmed July. http://www.ted.com/talks/chimamanda_adichie_ the_danger_of_a_single_story?language $=$ en .

Agyekum, Kofi. 2002. "Menstruation as a Verbal Taboo among the Akan of Ghana." Journal of Contemporary Ethnography 58 (2): 367-87.

Ahmed, Beenish. 2015. "Bloody Hell: Does Religion Punish Women for Menstruating?” Vice, June 20. https://www.vice.com/en_us/article/7bdbw9/ bloody-hell-menstruating-while-religious- 235 .

Akin, David. 2003. “Concealment, Confession, and Innovation in Kwaio Women's Taboos." American Ethnologist 30 (3): 381-400.

Akwasi, Tiffany. 2018. "Puberty Rites in Ghana-Types and Significance." Accessed June 4, 2019. https://yen.com.gh/108440-this-yen-gh-believes-our-manifesto. html\#108440.

Alayyan, Sarra, and Agence France-Presse. 2017. "Nepal Bans Use of 'Menstrual Huts' to Banish Women from Homes." The Telegraph, August 9. https:// www.telegraph.co.uk/news /2017/08/09/nepalbans-use-menstrualhuts-banish-women-homes/.

Allan, Keith, and Kate Burridge. 2006. Forbidden Words: Taboo and the Censoring of Language. Cambridge: Cambridge University Press.

Amberston, Celu. 1994. Blessings of the Blood: A Book of Menstrual Rituals for Women. Vancouver: Beach Holme Publisher.

Appell, Laura. 1988. "Menstruation among the Rungus of Borneo: An Unmarked Category." In Blood Magic: The Anthropology of Menstruation, edited by Thomas Buckley and Alma Gottlieb, 94-112. Berkeley: University of California Press.

Austin, John. 1962. How to Do Things with Words. Oxford: Clarendon Press.

Baldy, C. Risling. 2016. "mini-k'iwh'e:n (For that Purpose-I Consider Things) (Re)writing and (Re)righting Indigenous Menstrual Practices to Intervene on Contemporary Menstrual Discourse and the Politics of Taboo." Cultural Studies $\leftrightarrow$ Critical Methodologies 17 (1): 21-29.

2018. We Are Dancing for You: Native Feminisms and the Revitalization of Women's Coming-of-Age Ceremonies. Seattle: University of Washington Press.

Beardsley, Felicia R. 1999. "Yap Menstrual Hut-Yap State, Federated State of Micronesia." Micronesian Diary: A Continuing Report from the Field, April 10. http://www.intangible.org/Features/micronesia/text/Yapl2.html. 
Beckwith, Ryan Teague. 2015. "Trump: Debate Moderator Had 'Blood Coming Out of Her Wherever." Time, August 8.

Bell, Adey. 2014. "3 Ways to Have a More Potent Period . . f for Good." YouTube, April 29. https://www.youtube.com/watch?v=K_vwPtoTzMY.

Bobel, Chris. 2010. New Blood: Third-Wave Feminism and the Politics of Menstruation. New Brunswick: Rutgers University Press.

- 2019. The Managed Body: Developing Girls and Menstrual Health in the Global South. New York: Palgrave Macmillan.

Bradner, Eric. 2015. "Businesswoman Stands by Her Man-Only View of Presidency." CNN Politics, April 18. https://www.cnn.com/2015/04/18/politics/ceo-women-shouldnt-be-president/index.html.

Brumberg, Joan Jacobs. 1993. "'Something Happens to Girls:' Menarche and the Emergence of the Modern American Hygienic Imperative." Journal of the History of Sexuality 4 (1): 99-127.

Buckley, Thomas. 1988. "Menstruation and the Power of Yurok Women." In Blood Magic: The Anthropology of Menstruation, edited by Thomas Buckley and Alma Gottlieb, 187-209. Berkeley: University of California Press.

Buckley, Thomas, and Alma Gottlieb. 1988a. "A Critical Appraisal of Theories of Menstrual Symbolism." In Blood Magic: The Anthropology of Menstruation, edited by Thomas Buckley and Alma Gottlieb, 1-53. Berkeley: University of California Press.

—, eds. 1988b. Blood Magic: The Anthropology of Menstruation. Berkeley: University of California Press.

Cardiff, Cassandra. 2016. "The Gendering Period: Menarche and Womanhood in Low-income Communities of Bengaluru, India." M.Phil. thesis, Development Studies, Department of International Development/Queen Elizabeth House/St. Cross/College, University of Oxford.

Cauterucci, Christina. 2016. "Embracing 'the Blob' and Other Period Euphemisms." XX Factor: What Women Really Think, March 1. http://www.slate.com/blogs/ xx_factor/2016/03/01/euphemisms_for_periods_are_the_best.html.

Chrisler, Joan C. 2011. "Leaks, Lumps, and Lines: Stigma and Women's Bodies." Psychology of Women Quarterly 35 (2): 202-14.

Cicurel, Inbal, and Rachel Sharaby. 2007. "Women in the Menstruation Huts: Variations in Preserving Purification Customs among Ethiopian Immigrants." Journal of Feminist Studies in Religion 23 (2): 69-84.

Clancy, Kate. n.d. "Period. With Kate Clancy." http://kateclancy.com.

Clemmer, Cass. 2016. The Adventures of Toni the Tampon: A Period Coloring Book. N.p.: Bloody Queer Publishing.

2017. "Comments in Panel on 'The Menstrual Movement: Gender Inclusivity'." PeriodCon (Conference Organized by Period: The Menstrual Movement), New York, NY, November 18.

Comaroff, John, and Jean Comaroff. (1991) 1997. Of Revelation and Revolution. 2 vols. Chicago: University of Chicago Press.

Coronil, Fernando. 1997. The Magical State: Nature, Money, and Modernity in Venezuela. Chicago: University of Chicago Press.

Daniels, Lee A. 1991. "Child Becomes Woman in Traditional Akan Rite." New York Times, July 15. Accessed June 3, 2019. https://www.nytimes. $\mathrm{com} / 1991 / 07 / 15 /$ nyregion/child-becomes-woman-in-traditional-akan-rite. html?searchResultPosition $=4$. 
DeLuca, Robyn Stein. (2014) 2015. “The Good News about PMS.” Ted Talk, March 17, 2015. https://www.youtube.com/watch?v=aI8KiPiVLyY.

Ernster, V. L. 1975. “American Menstrual Expressions.” Sex Roles 1 (1): 3-13.

Escaja, Tina. 2018. “13 Lunas 13/13 Moons 13: A Video-Project about Sexuality and Menstruation." Journal of International Women's Studies 19 (3): 215-24.

Fahs, Breanne. 2016. "Smear It on Your Face: Menstrual Art, Performance, and Zines as Menstrual Activism." In Out for Blood: Essays on Menstruation and Resistance, 105-16. Albany: SUNY Press.

Farrell, Kate, ed. 2018. Period: Twelve Voices Tell the Bloody Truth. New York: Macmillan.

Fedele, Anna. 2014. "Reversing Eve's Curse: Mary Magdalene, Mother Earth and the Creative Ritualization of Menstruation." Journal of Ritual Studies 28 (2): 23-36.

Gandhi, Kiran. 2015. "Here's Why I Ran the London Marathon on the First Day of My Period-And Chose Not to Wear a Tampon." The Independent, August 14. https://www.independent.co.uk/voices/comment/heres-why-i-ran-thelondon-marathon-on-the-first-day-of-my-period-and-chose-not-to-wear-a-tampon-10455176.html.

Goffman, Erving. 1963. Stigma: Notes on the Management of Spoiled Identity. New York: Simon and Schuster.

Gottlieb, Alma. 1988a. "American Premenstrual Syndrome: A Mute Voice." Anthropology Today 4 (6): 10-13.

- 1988b. "Menstrual Cosmology among the Beng of Ivory Coast." In Blood Magic: The Anthropology of Menstruation, edited by Thomas Buckley and Alma Gottlieb, 55-74. Berkeley: University of California Press.

- 1989. "Witches, Kings, and the Sacrifice of Identity; or, The Power of Paradox and the Paradox of Power among the Beng of Ivory Coast." In Creativity of Power: Cosmology and Action in African Societies, edited by W. Arens and Ivan Karp, 245-71. Washington, DC: Smithsonian Institution Press.

. 1992. Under the Kapok Tree: Identity and Difference in Beng Thought. Bloomington: Indiana University Press.

Gupta, Aditi, et al. n.d. Menstrupedia Comic: The Friendly Guide to Periods for Girls. Accessed June 5, 2019. https://www.menstrupedia.com.

Hackett, Conrad, and David McClendon. 2017. "Christians Remain World's Largest Religious Group, but They Are Declining in Europe." Pew Research Center, FacTank, News in the Numbers, April 5. https://www.pewresearch.org/facttank/2017/04/05/christians-remain-worlds-largest-religious-group-but-they-are-declining-in-europe/ft_17-04-05_projectionsupdate_globalpop640px/.

Haleem, M. A. S. Abdel. 2011. "Euphemism in the Qur'an: A Case Study of Marital Relations as Depicted in Q. 2:222-3." Journal of Qur'anic Studies 13 (1): 125-31. Hogbin, Ian. (1970) 1996. The Island of Menstruation Men: Religion in Wogeo, New Guinea. N.p.: Waveland Press.

Hoskins, Janet. 2002a. "The Menstrual Hut and The Witch's Lair in Two Eastern Indonesian Societies.” Ethnology 41 (4): 317-33.

— ed. 2002b. "Blood Mysteries: Beyond Menstruation as Pollution." Ethnology 41 (4): 299-390 (special issue).

Houppert, Karen. 1999. The Curse: Confronting the Last Unmentionable Taboo. New York: Farrar, Strauss \& Giroux.

Kadariya, Shanti, and Arja R. Aro. 2015. "Champadi Practice in Nepal: Analysis of Ethical Aspects." Medicolegal and Bioethics 5: 53-58. https://www.dovepress. 
com/chhaupadi-practice-in-nepal-ndash-analysis-of-ethical-aspects-peer-reviewed-fulltext-article-MB.

Kadir, R. A., M. Edlund, and S. von Mackensen. 2010. "The Impact of Menstrual Disorders on Quality of Life in Women with Inherited Bleeding Disorders." Haemophilia 16 (5): 832-39.

Keesing, Roger. 1982. Kwaio Religion: The Living and the Dead in a Solomon Islands Society. New York: Columbia University Press.

Khoja-Moolji, Shenila, and Esther O. Ohito. 2018. "Containing the Leakiness of Impure Inhumans: Bleeding Third-World Bodies and the Confining Cultural Politics of Menstrual Hygiene Campaigns." In Youth Sexualities: Public Feelings and Contemporary Cultural Politics, edited by Susan Talburt, 107-28. Santa Barbara, CA: ABL-CIO Press.

Kissling, Elizabeth Arveda. 1996. “'That's Just a Basic Teen-age Rule:' Girls' Linguistic Strategies for Managing the Menstrual Communication Taboo." Journal of Applied Communication Research 24 (4): 292-309.

Kutis, Barbara. 2019. "The Contemporary Art of Menstruation: Embracing Taboos, Breaking Boundaries, and Making Art." In Menstruation Now: What Does Blood Perform? edited by Berkeley Kaite, 109-34. Ontario: Demeter Press.

Lahiri-Dutt, Kuntala. 2014. "Medicalising Menstruation: A Feminist Critique of the Political Economy of Menstrual Hygiene Management in South Asia." Gender, Place and Culture: A Journal of Feminist Geography 22 (8): 1-19.

Lancet, The. 2018. Editorial: "Normalising Menstruation, Empowering Girls." The Lancet/Child \& Adolescent Health 2, no. 6 (June 1): 379. https://doi. org/10.1016/S2352-4642(18)30143-3.

Lee, Janet. 1994. "Menarche and the (Hetero)Sexualization of the Female Body." Gender \& Society 8 (3): 43-62.

Lessa, William Armand. 1966. Ulithi: A Micronesian Design for Living. New York: Holt, Rinehart \& Winston.

Little, Peter C. 2012. "Another Angle on Pollution Experience: Toward an Anthropology of the Emotional Ecology of Risk Mitigation." Ethos: Journal of the Society for Psychological Anthropology 40 (4): 431-52.

Lizzio, Celene Ayat. 2013. "Gendering Ritual: A Muslima's Reading of the Laws of Purity and Ritual Preclusion." In Muslima Theology: The Voices of Muslim Women Theologians, edited by Ednan Aslan, Marcia Hermansen, and Elif Medeni, 167-80. Bern, Switzerland: Peter Lang.

Maggi, Wynne. 2002. Our Women Are Free: Gender and Ethnicity in the Hindukush. Ann Arbor: University of Michigan Press.

Manica, Daniela Tonelli, and Clarice Rios. 2017. “(In)visible Blood: Menstrual Performances and Body Art" (Dossier: On Rituals and Performances). Vibrant: Virtual Brazilian Anthropology 14 (1). http://www.vibrant.org.br/ lastest-issue-v-14-n-1-01-042017/.

Mazuz, Haggai. 2012. "Menstruation and Differentiation: How Muslims Differentiated Themselves from Jews Regarding the Laws of Menstruation.” Der Islam (Berlin) 87 (1/2): 204-23.

McLintock, Claire. 2018. "Women with Bleeding Disorders: Clinical and Psychological Issues." Haemophilia 24 (S6): 22-28. https://onlinelibrary.wiley. com/doi/full/10.1111/hae.13501. 
Mead, Margaret. 1935. Sex and Temperament in Three Primitive Societies. New York: William Morrow.

- 1949. Male and Female: A Study of the Sexes in a Changing World. New York: William Morrow.

Miner, Horace. 1956. "Body Ritual among the Nacirema." American Anthropologist 58 (3): 503-7.

Moeran, Brian. 2014. "Business, Anthropology, and Magical Systems: The Case of Advertising." 2014 Ethnographic Praxis in Industry Conference Proceedings, 119-32.

Morrow, Laura. 2017. "Israelite Ritual Law Concerning the Menstruant in Context: Embodiment and Meaning in Ancient Mesopotamia and Ancient Israel." Unpublished paper, Andrews University. https://digitalcommons.andrews.edu/ cgi/viewcontent.cgi?article $=1007 \&$ context $=$ papers.

Mukherjee, Purpa. 2009. "Difference between Syndrome and Disease." Difference between Similar Terms and Objects, October 29. http://www.differencebetween. net/science/health/difference-between-syndrome-and-disease/.

Newton, Victoria Louise. 2016. “'Auntie's Come to Tea': Menstrual Euphemism.” In Everyday Discourses of Menstruation: Cultural and Social Perspectives, 133-45. New York: Palgrave Macmillan/Springer.

Nilson, Ingrid. n.d. "Period Vids!" IngridNilsen. https://www.youtube.com/ watch?v=bjHSxdR60b8\&list=PLMli3KIg6MX9HXhBJA94GXwS_W_Du8tiE.

O'Flynn, Norma. 2006. "Menstrual Symptoms: The Importance of Social Factors in Women's Experiences." British Journal of General Practice 56 (533): 950-57.

O'Grady, Kathleen. 2003. "The Semantics of Taboo: Menstrual Prohibitions in the Hebrew Bible." In Wholly Woman, Holy Blood: A Feminist Critique of Purity and Impurity, edited by Kristin De Troyer, et al., 1-28. Harrisburg, PA: Trinity Press International.

Okamoto, Nadya. 2018. Period Power: A Manifesto for the Menstrual Movement. New York: Simon and Schuster.

O'Keefe, Theresa. 2006. "Menstrual Blood as a Weapon of Resistance." International of Feminist Journal of Politics 8 (4): 535-56.

Pawliková-Vilhanová, Viera. 2007. "Christion Missions in Africa \& Their Role in the Transformation of African Societies." Asian and African Studies 16 (2): 249-60.

Pedersen, L. 2002. "Ambiguous Bleeding: Purity and Sacrifice in Bali." Ethnology 41 (4): 303-15.

Pedraza, Andrea Pizarro. 2018. "Introduction." In Linguistic Taboo Revisited: Novel Insights from Cognitive Perspectives, edited by Andrea Pizarro Pedraza, 1-9. Berlin/ Boston: Mouton De Gruyter.

Pew Research Center. 2015. "The Future of World Religions: Population Growth Projections, 2010-2050." Pew Research Center-Religion and Public Life, April 2. http://www.pewforum.org/2015/04/02/religious-projections-2010-2050/.

Phipps, William E. 1980. "The Menstrual Taboo in the Judeo-Christian Tradition." Journal of Religion and Health 19 (4): 298-303.

Pierce, Mason. 2017. "Comments in Panel on 'The Menstrual Movement: Gender Inclusivity'.” PeriodCon, New York, NY, November 18.

Pinkerton, Joanne V. 2017. “Absence of Menstrual Periods (Amenorrhea).” Merck Manual-Professional Version. Accessed May 29, 2019. https://www.merckmanuals.com/professional/gynecology-and-obstetrics/menstrual-abnormalities/ amenorrhea. 
Rattray, R. S. 1927. Religion and Art in Ashanti. Oxford: Clarendon Press.

Ren, Liqi, Denis Simon, and Jianfeng Wu. 2018. "Meaning in Absence: The Case of Tampon Use among Chinese Women.” Asian Journal of Women's Studies 24 (1): 28-46.

Schutz, Alfred. 1967. The Phenomenology of the Social World. Evanston, IL: Northwestern University Press.

Scott, Joan Wallach. 2007. The Politics of the Veil. Princeton: Princeton University Press.

Seear, Kate. 2009. "The Etiquette of Endometriosis: Stigmatisation, Menstrual Concealment and the Diagnostic Delay." Social Science and Medicine 69 (8): $1220-27$.

Stein, Elissa, and Susan Kim. 2009. Flow: The Cultural Story of Menstruation. New York: St. Martin's Press.

Steinem, Gloria. 1978. "If Men Could Menstruate." Ms. Magazine, October.

Steiner, Franz B. (1950-52) 1956. Taboo. London: Cohen \& West.

Stolberg, Michael. 2000. "The Monthly Malady: A History of Premenstrual Suffering." Medical History 44: 301-22.

Studd, John, et al. n.d. "About PMS." National Association for Premenstrual Syndrome. http://www.pms.org.uk/About.

Tambiah, Stanley J. 1968. "The Magical Power of Words." Man 3, no. 2 (n.s.): 175-208.

TedMed. n.d. "Linda B. Rosenthal in a Nutshell." https://blog.tedmed.com/ making-menstruation-matter/.

Thornton, Leslie-Jean. 2013. “'Time of the Month' on Twitter: Taboo, Stereotype and Bonding in a No-Holds-Barred Public Arena.” Sex Roles 68: 41-54.

Thorpe, J. R. 2016. "Menstrual Huts Still Exist-And Here's Why That's A Problem.” Bustle, December 9. https://www.bustle.com/articles/198540menstrual-huts-still-exist-and-heres-why-thats-a-problem.

U.S. Department of Health and Human Services. 2018. "Premenstrual Syndrome (PMS)," March 16. Office on Women's Health, Office of the Assistant Secretary for Health, U.S. Department of Health and Human Services. https://www.womenshealth.gov/menstrual-cycle/premenstrual-syndrome.

Walter, Laura Maylene. 2016. "Museum of Menarche." Ninth Letter (Fall/Winter 2016). http://www.ninthletter.com/journal/147-13-2-fall-winter-2016.

Weiss-Wolf, Jennifer. 2017. Periods Gone Public: Taking a Stand for Menstrual Equity. New York: Arcade Publishing.

White, Pamela, Sunita Sharma, and Sunil Kumar Das. 2013. "Culture Clash: Menstruation Taboos and ODF in Nepal." Community-Led Total Sanitation, December 13. CommunityLedSanitation.org.

Williams, Laura. n.d. "The Best 10 Yoga Poses for a Painless Period." Zenward. http://blog.zenward.com/10-best-yoga-poses-painless-period/.

Wood, Charles T. 1981. "The Doctor's Dilemma: Sin, Salvation, and the Menstrual Cycle in Medieval Thought." Speculum 56 (4): 710-27.

Wortham, Jenna. 2014. "Our Bodies, Our Apps: For the Love of Period-Trackers." New York Times, January 23. https://bits.blogs.nytimes.com/2014/01/23/ our-bodies-our-apps-for-the-love-of-period-trackers / .

Yang, Heyi, et al. 2012. "Proteomic Analysis of Menstrual Blood." Molecular \& Cellular Proteomics 11 (10): 1024-35. www.mcponline.org. 
Open Access This chapter is licensed under the terms of the Creative Commons Attribution 4.0 International License (http://creativecommons.org/licenses/ by $/ 4.0 /)$, which permits use, sharing, adaptation, distribution and reproduction in any medium or format, as long as you give appropriate credit to the original author(s) and the source, provide a link to the Creative Commons license and indicate if changes were made.

The images or other third party material in this chapter are included in the chapter's Creative Commons license, unless indicated otherwise in a credit line to the material. If material is not included in the chapter's Creative Commons license and your intended use is not permitted by statutory regulation or exceeds the permitted use, you will need to obtain permission directly from the copyright holder. 